\begin{tabular}{cc|c}
\hline BenthAm open & $\begin{array}{c}\text { The Open Construction \& Building } \\
\text { Technology Journal } \\
\text { CrossMark }\end{array}$ \\
& Content list available at: www.benthamopen.com/TOBCTJ/ \\
DoI: $10.2174 / 1874836801610010182$ & \\
\hline
\end{tabular}

\title{
Retraction Notice: Study on Direct Waterproof Construction of Basement Roof in Planting Area
}

Zhao Yongdong $^{1}$, Zhao Yang ${ }^{2, *}$ and Wangyuanyuan ${ }^{2}$

${ }^{I}$ Department of Construction Engineering, Yancheng Institute of Technology, Jiangsu, China

${ }^{2}$ Nanjing University of Technology, Jiangsu, China

\section{RETRACTION}

The Publisher and Editor have retracted this article [1] in accordance with good ethical practices. After thorough investigations we believe that the peer review process was compromised. The article was published online on 31-12-2014.

\section{REFERENCE}

[1] Z. Yongdong, Z. Yang, and Wangyuanyuan, "Study on Direct Waterproof Construction of Basement Roof in Planting Area", Open Constr. Build. Technol. J., vol. 8, pp. 413-416, 2014.

(C) Yongdong et al.; Licensee Bentham Open.

This is an open access article licensed under the terms of the Creative Commons Attribution-Non-Commercial 4.0 International Public License (CC BY-NC 4.0) (https://creativecommons.org/licenses/by-nc/4.0/legalcode), which permits unrestricted, non-commercial use, distribution and reproduction in any medium, provided the work is properly cited.

\footnotetext{
* Address correspondence to this author at the Hope road Road No. 1, Yancheng, China. Postcard: Yancheng Institute of Technology, China; Tel:
} 18936319135; E-mail: 211213@163.com 